\title{
Зміни гемодинаміки при використанні різних інфузійних розчинів під час коронарного шунтування на працюючому серці
}

\author{
Мазур А. П., Гурін П. В., Бабіч М. М. \\ ДУ «Національний інститут хірургії та трансплантології імені О. О. Шалімова НАМН України» (Київ)
}

\begin{abstract}
Вивчено зміни гемодинаміки під час коронарного шунтування на працюючому серці. Наведено порівняльний аналіз застосування колоїдних і кристалоїдних розчинів на етапах формування дистального анастомозу під час коронарного шунтування на працюючому серці. У дослідження було включено 80 пацієнтів, оперованих у Національному інституті хірургії та трансплантології імені О. О. Шалімова з приводу ішемічної хвороби серця, яким було виконано коронарне шунтування на працюючому серці. У групу дослідження було включено 40 пацієнтів, яким у програмі інфузійної терапії інтраопераційного періоду застосовували розчин гідроксиетилкрохмалю 130/0,4 або 4\% розчин желатину. Групу порівняння склали 40 пацієнтів, яким в інтраопераційному періоді були застосовані виключно кристалоїдні розчини. Аналізували зміни серцевого індексу, артеріального тиску, тиску в легеневій артерії, центрального венозного тиску, результати загального і біохімічного аналізу крові, електролітний, кислотно-основний і газовий склад крові. Отримані результати продемонстрували, що при застосуванні колоїдних розчинів показники центральної гемодинаміки на етапі формування дистального анастомозу (серцевого індексу, артеріального тиску, тиску в легеневій артерії та центрального венозного тиску) були достовірно вищими, ніж при застосовуванні кристалоїдних розчинів. Проте зниження показників центральної гемодинаміки у пацієнтів, у яких були застосовані кристалоїдні розчини, не були критичними і дозволяли виконувати коронарне шунтування на працюючому серці в усіх пацієнтів без залучення штучного кровообігу.
\end{abstract}

Ключові слова: коронарне шунтування, серцевий індекс, колоїдні розчини, кристалоїдні розчини, гемодинаміка.

Штучний кровообіг (ШК), незважаючи на досконалість сучасного технічного забезпечення, залишається антифізіологічною процедурою, що має ряд специфічних ускладнень з боку як серця, так і інших органів і систем. Серед найбільш поширених - неврологічні розлади, коагулопатичні кровотечі, ускладнення з боку легень [1, 2]. У низці випадків патологічні зміни, що відбулися на аноксичному етапі операції, є незворотними і призводять до ушкодження міокарда [3].

Техніка виконання коронарного шунтування (КШ) на працюючому серці за останні роки значно розвинулась. Проте накладання дистальних анастомозів на задніх і бічних судинах серця може характеризуватися нестабільною гемодинамікою, що супроводжується зниженням серцевого індексу (CI) та артеріального тиску (АТ) [4]. Хоча порушення волемічного статусу є однією з найпоширеніших причин нестабільності гемодинаміки при виконанні будь-яких кардіохірургічних втручань, найчастіше вони виникають саме при виконанні КШ на працюючому серці. Зниження СI внаслідок гіповолемії призводить до гіпоперфузії тканин, порушення тканинного метаболізму, збільшення частоти периопераційних ускладнень і підвищення післяопераційної летальності $[5,6]$. В той же час гіперволемія збільшує напруження міокарда шлуночків, підвищує роботу серця і споживання кисню міокар- дом, призводить до гемодилюції, коагулопатії та накопичення рідини в інтерстиціальному просторі.

Під час операції об’єм циркулюючої крові (ОЦК) підтримується кристалоїдними розчинами i, зрештою, колоїдом, що залишається в судинному руслі, тоді як від 30 до 60\% кристалоїдних розчинів можуть бути «втрачені» в інтерстиційному просторі [7]. Вважається, з одного боку, що використання колоїдних розчинів для підтримки ОЦК під час оперативного втручання є доцільним при суттєвій крововтраті, з іншого - що використання синтетичних колоїдів впливає на коагуляційний гемостаз, а це певною мірою призводить до збільшення крововтрати. Тому проблема вибору оптимальної тактики інфузійної терапії в периопераційному періоді досі залишається невирішеним питанням [8].

Мета дослідження - вивчити зміни гемодинаміки під час КШ на працюючому серці при використанні різних інфузійних розчинів.

Матеріали і методи. В основу дослідження покладено проспективний аналіз проведених оперативних втручань у пацієнтів, яким із січня 2015 по серпень 2016 року було виконано ізольоване КШ на працюючому серці. Критеріями виключення пацієнтів із дослідження були фракція викиду лівого шлуночка менша за 50\%, початковий рівень креатиніну крові 
$>140$ мкмоль/л, рівень гемоглобіну < 120 г/л, кількість тромбоцитів $<180 \times 10^{9} / л$, доопераційна коагулопатія, печінкова дисфункція (АЛТ >40 ОД/л, АСТ >40 ОД/л), повторна операція КШ, ургентне оперативне втручання. Усім пацієнтам антитромбоцитарні препарати (клопідогрель, тікагрелор) та аспірин були відмінені більше ніж за 5 днів до оперативного втручання. Даним критеріям відповідало 80 пацієнтів, які і були включені в дослідження.

Пацієнти були розподілені на дві рівні групи по 40 осіб: 1-ша група (група дослідження) - пацієнти, у яких в інтраопераційному періоді застосовувався розчин гідроксиетилкрохмалю (ГЕК) 130/0,4 або розчин $4 \%$ желатину (максимальна доза не перевищувала 15 мл/кг); 2-га група (група порівняння) - пацієнти, у яких колоїдні розчини в інтраопераційному періоді не застосовувались, а в програму інфузійної терапії були включені лише кристалоїдні розчини.

Кожному пацієнту після індукції в анестезію та інтубації трахеї встановлювали ехокардіографічний датчик під контролем ларингоскопу в кардіальний відділ шлунка таким чином, щоб отримати оптимальну візуалізацію поперечного перерізу міокарда лівого шлуночка на рівні папілярних м'язів. Глибина і підсилення були підібрані індивідуально для кожного пацієнта і не змінювалися до закінчення операції.

Катетеризація легеневої артерії внутрішньовенною канюлею 20 g здійснювали після стернотомії. Даний метод виміру тиску в легеневій артерії (ТЛА) був вибраний, оскільки класична методика вимірювання ТЛА за допомогою катетера Сван-Ганцу, по-перше, має багато ускладнень (пункція сонної артерії, утворення гематоми, пневмоторакс, порушення ритму і провідності, розрив легеневої артерії), а по-друге, даний катетер не зареєстрований до використання на території України. Завдяки цьому проводили моніторинг ТЛА, а також забір проб крові для визначення кислотно-основного стану (КОС), лактату і розрахунку артеріовенозної різниці за киснем.

CI розраховували у такий спосіб. На початку операції, на етапі шунтування передньої міжшлуночкової гілки (ПМШГ) лівої коронарної артерії (ЛКА) та після закінчення операції СІ визначали за допомогою черезстравохідної ехокардіографіії (ЧСЕхоКГ) за формулою:

$\mathrm{CI}=((\mathrm{KДО}-\mathrm{KCO}) \mathrm{x} С \mathrm{C}) /$ площу поверхні тіла (ППТ),

де КДО - кінцево-діастолічний об'єм, мл;

КСО - кінцево-систолічний об'єм, мл;

ЧСС - частота серцевих скорочень за 1 хв.

Під час шунтування правої коронарної артерії (ПКА) та огинаючої гілки (ОГ) ЛКА, коли обчислення за допомогою ЧСЕхоКГ було ускладненим, СІ обчислювали за допомогою формули Фіка:

$\mathrm{CI}=\left(\mathrm{VO}_{2} /\left(1,34 \times \mathrm{Hb} \times\left(\mathrm{SaO}_{2}-\mathrm{SvO}_{2}\right)+\left(0,003 \times \mathrm{PaO}_{2}\right)\right) / \Pi \Pi \mathrm{T}\right.$, де $\mathrm{VO}_{2}$ - споживання кисню, мл/хв.;

1,34 - константа Гюфнера (відображає здатність гемоглобіну зв'язувати кисень);

$\mathrm{Hb}$ - концентрація гемоглобіну в крові, г/л;

$\mathrm{SaO}_{2}$ - сатурація гемоглобіну артеріальної крові, \%;

$\mathrm{SvO}_{2}$ - сатурація гемоглобіну венозної крові, \%;

$\mathrm{PaO}_{2}$ - парціальний тиск кисню в артеріальній крові, мм рт. ст.

Показник $\mathrm{VO}_{2}$ обчислювали за різницею вмісту кисню в контурі газоаналізатору апарату ШВЛ. Отриманий результат помножували на величину хвилинного об'єму дихання.

Результати та обговорення. Пацієнти досліджуваних груп не відрізнялися між собою за клінічними та лабораторними показниками перед проведенням оперативного втручання. Середній вік пацієнтів 1-ої групи становив $60,2 \pm 10$ років, 2 -ої $-59,9 \pm 8,8$ років $(\mathrm{p}=0,88)$. Усі пацієнти мали стенокардію напруження різного функціонального класу, а оцінка периопераційного ризику за шкалою EUROSCORE склала $1,12 \pm 0,33 \%$ і $1,1 \pm 0,3 \%$ відповідно у пацієнтів 1-ї та 2-ї групи. Також не було виявлено суттєвих відмінностей у доопераційних показниках гемоглобіну, коагулограми тощо.

Порівняння показників центральної гемодинаміки здійснювали на етапі формування дистального анастомозу між лівою внутрішньою грудною артерією (ЛВГА) або аутовеною та коронарною артерією.

Анастомоз між ПМШГ ЛКА та ЛВГА був виконаний у 39 пацієнтів $(97,5 \%)$ групи дослідження та 40 пацієнтів (100\%) групи порівняння.

Для встановлення епікардіального стабілізатора на ділянку коронарної артерії для іiї шунтування серце зміщують наперед шляхом підкладання під нього серветки або підтяганням догори тракційних швів. В усіх випадках встановлення епікардіального стабілізатора призводить до помірного тиску на лівий шлуночок. Виникає незначне зменшення кінцево-систолічного та кінцево-діастолічного об’єму лівого шлуночка. Компресія лівого шлуночка більш виражена в передньо-задньому напрямі і на верхівці внаслідок прямого тиску епікардіального стабілізатора на передню стінку і на верхівку лівого шлуночка. Завдяки тому, що кінцево-діастолічний і кінцево-систолічний об'єми зменшуються одночасно після накладання стабілізатора, фракція викиду лівого шлуночка змінюється незначно.

Стінка правого шлуночка тонша, ніж стінка лівого шлуночка, тому правий шлуночок більш чутливий до компресії. Компресія епікардіального стабілізатора призводить до підвищення кінцево-діастолічного тиску обох шлуночків, зниження артеріального тиску, незначного підвищення центрального венозного тиску (ЦВТ).

Показники центральної гемодинаміки при формуванні дистального анастомозу між ЛВГА та ПМШГ 


\section{Таблиця 1}

Показники гемодинаміки на етапі формування дистального анастомозу між ЛВГА та ПМШГЛКА

\begin{tabular}{|c|c|c|c|}
\hline Показник & $\begin{array}{c}\text { Група } 1 \\
\mathrm{~N}=39, \mathrm{M} \pm \mathrm{SD}\end{array}$ & $\begin{array}{c}\text { Група } 2 \\
\mathrm{~N}=40, \mathrm{M} \pm \mathrm{SD}\end{array}$ & $\mathbf{P}$ \\
\hline AT сер. (мм рт. ст.) & $95,3 \pm 8,2$ & $86,6 \pm 7,9$ & 0,0001 \\
\hline ТЛА сер. (мм рт. ст.) & $17,1 \pm 2,8$ & $16,3 \pm 1,7$ & 0,12 \\
\hline $\mathrm{Cl}(л /$ хв./M²) & $2,95 \pm 0,42$ & $2,62 \pm 0,35$ & 0,0003 \\
\hline ЦВТ (мм вод. ст.) & $65 \pm 9,7$ & $45,6 \pm 13,1$ & 0,0001 \\
\hline $\mathrm{SvO}_{2}(\%)$ & $71,8 \pm 1,4$ & $72,5 \pm 3,7$ & 0,27 \\
\hline Лактат (ммоль/л) & $1 \pm 0,27$ & $0,98 \pm 0,27$ & 0,74 \\
\hline
\end{tabular}

ЛКА при використанні розчинів ГЕК і кристалоїдних розчинів наведено в табл. 1.

Як можна побачити з таблиці, при використанні колоїдних розчинів СІ був вищим на $12,5 \%$, а АТ середнє - на 10\%. Проте в групі, де застосовувалися кристалоїдні розчини, CI на етапі шунтування ПМШГ не знижувався нижче за 2 л/хв./ $\mathrm{M}^{2}$, а АТ середнє - нижче за 70 мм рт. ст. ЦВТ та ТЛА ср. достовірно не відрізнялись між групами пацієнтів. Показниками адекватної тканинної перфузії виступають $\mathrm{SvO}_{2}$ і концентрація лактату плазми. $\mathrm{SvO}_{2}$ в обох групах не зменшувалася нижче $70 \%$, а концентрація лактату не підвищувалася більше 2 ммоль/л.

Шунтування ПКА проводили у 35 (87,5\%) пацієнтів групи дослідження і 31 (77,5\%) пацієнта групи порівняння. При виконанні дистального анастомозу гілок правої ПКА зміни гемодинаміки пов'язані в основному з помірною компресією правих відділів серця. При шунтуванні ПКА верхівка серця виводиться назовні, при цьому зберігається положення Тренделенбурга i стіл ротується ліворуч для покращення огляду операційної рани. Виникає компресія правого шлуночка стабілізатором, а ліві відділи серця змішуються без стискання між двома поверхнями. Завдяки цьому не виникає значного зниження АТ.

Показники центральної гемодинаміки при формуванні дистального анастомозу між аортою та ПКА при використанні колоїдних розчинів і кристалоїдних розчинів представлені в табл. 2.

Як можна побачити з таблиці, при застосуванні колоїдних розчинів величина СІ була вищою на $10 \%$, а АТ середне - на 13\%. Проте в групі порівняння СI на етапі формування дистального анастомозу між аортою та ПКА знижався до рівня, що не був критично нижчим, ніж 2 л/хв/ $\mathrm{M}^{2}$, а величина АТ середне - нижчою за 70 мм рт. ст. Показник $\mathrm{SvO}_{2}$ не зменшувався нижче $65 \%$, а концентрація лактату плазми реєструвалася на рівні, що відповідає адекватній тканинній перфузії на даному етапі операції, в обох групах.

\section{Таблиця 2}

Показники гемодинаміки на етапі формування дистального анастомозу між аортою та ПКА

\begin{tabular}{|c|c|c|c|}
\hline Показник & $\begin{array}{c}\text { Група } 1 \\
\mathrm{~N}=35, \mathrm{M} \pm \mathrm{SD}\end{array}$ & $\begin{array}{c}\text { Група } 2 \\
\mathrm{~N}=31, \mathrm{M} \pm \mathrm{SD}\end{array}$ & p \\
\hline AT сер. (мм рт. ст.) & $83,3 \pm 5,4$ & $72,7 \pm 6,2$ & 0,0004 \\
\hline ТЛА сер. (мм рт. ст.) & $24,2 \pm 1,8$ & $22,6 \pm 2,5$ & 0,0038 \\
\hline $\mathrm{Cl}\left(\mathrm{\Omega} / \mathrm{XB} . / \mathrm{M}^{2}\right)$ & $2,43 \pm 0,25$ & $2,2 \pm 0,28$ & 0,0004 \\
\hline ЦВТ (мМ вод. ст.) & $87,5 \pm 6,8$ & $83,4 \pm 18,6$ & 0,23 \\
\hline $\mathrm{SvO}_{2}(\%)$ & $72,3 \pm 2,9$ & $71,6 \pm 3,3$ & 0,36 \\
\hline Лактат (ммоль/л) & $1,7 \pm 0,34$ & $1,6 \pm 0,28$ & 0,2 \\
\hline
\end{tabular}

Шунтування ОГ ЛКА проводили у 33 (82,5\%) пацієнтів групи дослідження та 30 (75\%) пацієнтів групи порівняння. Гілки огинаючої артерії знаходяться на боковій стінці лівого шлуночка. Для їх позиціонування серце повинно бути зміщене праворуч і вгору. Для зручності експозиції латеральної поверхні серця використовують положення Тренделенбурга і ротацію операційного столу праворуч. Дислокація серця призводить до погіршення наповнення шлуночків, недостатності атріовентрикулярних клапанів. При огляді гілок огинаючої артерії хірург тимчасово зміщує серце і створює компресію на лівий шлуночок, що може призвести до появи шлуночкових екстрасистол, які будуть впливати на гемодинаміку. Знижується АТ середнє та CI. Корекція гемодинаміки необхідна вже в першій фазі підйому і повороту серця, для того щоб при встановленні стабілізатора не було різкого падіння АТ і порушень ритму. При позиціонуванні ОГ ЛКА значно зменшується порожнина лівого шлуночка, збільшується ліве передсердя, а правий шлуночок і передсердя піддаються значній компресії.

При ЧСЕхоКГ спостерігається зміщення міжпередсердної перегородки вліво, компресія порожнини правого шлуночка, зменшення розмірів лівого шлуночка. Нормалізація показників АТ забезпечує підтримку коронарного перфузійного тиску і кровоток через сформований анастомоз ЛВГА - ПМШГ ЛКА.

Артеріотомію і формування дистального анастомозу зі згинаючою артерією починають після стабілізації показників АТ та ЧСС. Стабілізація показників гемодинаміки забезпечувалася методом підвищення AT cep. за допомогою вазоконстрикторів, а також вибором оптимального положення серця і встановлення епікардіального стабілізатора без компресії шлуночків.

У табл. 3 наведено показники центральної гемодинаміки при формуванні дистального анастомозу між аортою та ОА при використанні колоїдних розчинів і кристалоїдних розчинів.

Як видно з таблиці, при шунтуванні басейна ОГ ЛКА зміни гемодинаміки найбільш виражені. У па- 


\section{Таблиця 3}

Показники гемодинаміки на етапі формування дистального анастомозу між аортою та OA

\begin{tabular}{|c|c|c|c|}
\hline Показник & $\begin{array}{c}\text { Група } 1 \\
\mathrm{~N}=33, \mathrm{M} \pm \mathrm{SD}\end{array}$ & $\begin{array}{c}\text { Група } 2 \\
\mathrm{~N}=30, \mathrm{M} \pm \mathrm{SD}\end{array}$ & p \\
\hline AT сер. (мм рт. ст.) & $78,3 \pm 3$ & $65,3 \pm 6$ & 0,0001 \\
\hline ТЛА сер. (мм рт. ст.) & $25,3 \pm 2,7$ & $27,4 \pm 2,2$ & 0,0013 \\
\hline $\mathrm{Cl}(л /$ хв./M²) & $2,34 \pm 0,11$ & $1,84 \pm 0,14$ & 0,0001 \\
\hline ЦВТ (мМ вод. ст.) & $93,1 \pm 6,5$ & $91 \pm 18$ & 0,53 \\
\hline $\mathrm{SvO}_{2}(\%)$ & $74,9 \pm 3,2$ & $74,2 \pm 2,8$ & 0,36 \\
\hline Лактат (ммоль/л) & $1,36 \pm 0,24$ & $1,3 \pm 0,29$ & 0,37 \\
\hline
\end{tabular}

цієнтів 1-ї групи СІ був вищим на 27\%, а АТ середнє на $20 \%$. ТЛА ср. хоча і був вищим, проте ця величина не була значною. У 6 (20\%) пацієнтів 2-ї групи застосовували інфузію допаміну в дозі 5-8 мкг/кг/хв.

Зниження серцевого індексу виникає за рахунок ліво- та правошлуночкової дисфункції та найбільш виражено при зміщенні серця з перикарда під час реваскуляризації ОГ ЛКА. Зниження АТ при дислокації серця може бути зменшено за рахунок збільшення переднавантаження, що продемонстровано у пацієнтів 1-ї групи. Системна гіпотензія може бути зумовлена порушенням викиду правого шлуночка внаслідок компресії правого передсердя і правого шлуночка при зміщенні і повороті серця. Якщо нормалізація СІ не відбувається після додаткової інфузії розчинів, то необхідна інфузія вазопресорів та/або інотропних препаратів.

\section{Висновки}

1. При шунтуванні судин передньої та бокової поверхні серця виникає компресія серця та зменшення КДО шлуночків, що призводить до зменшення ударного об'єму лівого шлуночка, зниження СI та АТ сер., підвищення ЦВТ та ТЛА сист. і ТЛА сер.

2. При шунтуванні судин задньої поверхні серця порушення гемодинаміки спричинені порушенням наповнення шлуночків унаслідок енуклеації (вертикалізації) серця, виникнення або посилення мітральної недостатності, обструкцією вивідних протоків і проявляються в зниженні АТ сер. до 25\%, CI до 27\%. У деяких випадках необхідна корекція гемодинаміки.
3. При використанні кристалоїдних розчинів спостерігаються виражені зміни гемодинаміки на етапах шунтування ОГ ЛКА порівняно з колоїдними розчинами, однак навіть при зниженні CI $<2$ л/хв./м² показники $\mathrm{SvO}_{2}$ та лактату не змінюються нижче референтних значень.

4. При плановому хірургічному втручанні рекомендоване використання кристалоїдних розчинів як базових у програмі периопераційної інфузійної терапії.

\section{Література}

1. Shaefi S, Mittel A, Loberman D, Ramakrishna H. OffPump Versus On-Pump Coronary Artery Bypass Grafting-A Systematic Review and Analysis of Clinical Outcomes. J Cardiothorac Vasc Anesth. 2019 Jan;33(1):232-244.

2. Wang Y, Shi X, Du R, Chen Y, Zhang Q. Off-pump versus on-pump coronary artery bypass grafting in patients with diabetes: a meta-analysis. Acta Diabetol. 2017 Mar;54(3):283-292.

3. Struck R, Wittmann M, Müller S, Meybohm P, Mbller A, Bagci S. Effect of Remote Ischemic Preconditioning on Intestinal Ischemia-Reperfusion Injury in Adults Undergoing On-Pump CABG Surgery: A Randomized Controlled Pilot Trial. J Cardiothorac Vasc Anesth. 2018 Jun;32(3):1243 -1247.

4. Vettath MP, Ravisankar M, Kopjar T, Kannan AV, Gangadharan N. Off-Pump Coronary Artery Bypass Grafting Improves Early Clinical Outcomes Including Operative Mortality. Heart Surg Forum. 2018 May 11;21(3):E151-E157.

5. Dekker AL, Geskes GG, Cramers AA, Dassen WR, Maessen JG, Prenger KB, van der Veen FH. Right ventricular support for off-pump coronary artery bypass grafting studied with bi-ventricular pressure--volume loops in sheep. Eur J Cardiothorac Surg. 2001 Feb;19(2):179-84.

6. Atasever B, Boer C, Speekenbrink R, Seyffert J, Goedhart $\mathrm{P}$, de Mol B, Ince C. Cardiac displacement during offpump coronary artery bypass grafting surgery: effect on sublingual microcirculation and cerebral oxygenation. Interact Cardiovasc Thorac Surg. 2011 Dec;13(6):573-7.

7. Zaar M, Lauritzen B, Secher NH, etal. Initial administration of hydroxyethyl starch vs. lactated Ringer after liver trauma in the pig. Br J Anaesth. 2009; 102:221-226.

8. Kelleher MC, Buggy DJ. Pendulum swings again: crystalloid or colloid fluid therapy? Br J Anaesth. 2014;113:335-337.

\title{
Haemodynamic Changes in Coronary Artery Bypass Grafting using Colloidal and Crystalloid Solutions
}

\author{
Mazur A., Gurin P., Babich M.
}

\section{O. O. Shalimov National Institute of Surgery and Transplantology National Academy of Medical Science of Ukraine (Kyiv)}

Changes in haemodynamics during off-pump coronary artery bypass grafting have been studied. The comparative analysis of the application of colloidal and crystalloid solutions at the stages of distal anastomosis formation during offpump coronary artery bypass grafting is given. The study included 80 patients operated at O. O. Shalimov National Institute of Surgery and Transplantology for ischemic heart disease, who underwent off-pump coronary artery bypass grafting. 
The study group included 40 patients who used hydroxyethylstarch (HES) 130/0.4 solution or 4\% gelatine solution in the intraoperative infusion therapy program. The comparison group consisted of 40 patients, which were exclusively crystalloid solutions in the intraoperative period. The changes in the cardiac index (CI), blood pressure (BP), pressure in the pulmonary artery (PAP), central venous pressure (CVP), the results of complete and biochemical blood tests, electrolyte, acid-base and gas composition of the blood were analysed. The statistical analysis of the material was carried out by standard methods using the application package MS Excel 2007 and Stat Plus 2007 Professional. Estimated mean, standard errors, statistical significance, Student's t-test were used to assess the intergroup difference, while the relationship between the indicators was determined by the Pearson correlation analysis. Changes in intracardiac haemodynamics occurring at the stages of off-pump coronary artery bypass grafting were studied. The obtained results showed that when using colloidal solutions, the values of central haemodynamics at the stage of distal anastomosis formation (CI, BP, PAP and CVP) were significantly higher than in patients treated with crystalloid solutions. However, the decline in central haemodynamics in patients treated with crystalloid solutions was not critical and allowed off-pump coronary artery bypass grafting to be performed in all patients without involvement of cardio-pulmonary bypass (CPB).

Key words: off-pump coronary artery bypass grafting, cardiac index, colloidal solutions, crystalloid solutions, haemodynamic changes. 